\title{
A Proteomic Study to Identify Soya Allergens - The Human Response to Transgenic versus Non-Transgenic Soya Samples
}

\author{
Rita Batista ${ }^{a, d}$ Isabel Martins ${ }^{d}$ Paul Jenöe Cândido Pinto Ricardo ${ }^{b, d}$ \\ Maria Margarida Oliveirac, $d$ \\ a Instituto Nacional de Saúde Dr. Ricardo Jorge, Lisboa, ${ }^{b}$ Instituto Superior de Agronomia, Universidade Técnica de \\ Lisboa, Lisboa, 'Departamento Biologia Vegetal, Faculdade de Ciências, Universidade de Lisboa, Lisboa, \\ dInstituto de Tecnologia Química e Biológica/Instituto de Biologia Experimental e Tecnológica, \\ Universidade Nova de Lisboa, Oeiras, Portugal; ${ }^{e}$ Division of Biochemistry, Biozentrum, University of Basel, \\ Basel, Switzerland
}

\section{Key Words}

Allergenicity $\cdot$ Food safety $\cdot$ Immune response •

Proteomics $\cdot$ Transgenic food

\begin{abstract}
Background: In spite of being among the main foods responsible for allergic reactions worldwide, soybean (Glycine max)-derived products continue to be increasingly widespread in a variety of food products due to their well-documented health benefits. Soybean also continues to be one of the elected target crops for genetic modification. The aim of this study was to characterize the soya proteome and, specifically, IgE-reactive proteins as well as to compare the $\lg \mathrm{E}$ response in soya-allergic individuals to genetically modified Roundup Ready soya ${ }^{\circledR}$ versus its non-transgenic control. Methods: We performed two-dimensional gel electrophoresis of protein extracts from a $5 \%$ genetically modified Roundup Ready flour sample and its non-transgenic control followed by Western blotting with plasma from 5 soyasensitive individuals. We used peptide tandem mass spectrometry to identify soya proteins (55 protein matches), specifically lgE-binding ones, and to evaluate differences between transgenic and non-transgenic samples. Results: We
\end{abstract}

identified 2 new potential soybean allergens - one is maturation associated and seems to be part of the late embryogenesis abundant proteins group and the other is a cysteine proteinase inhibitor. None of the individuals tested reacted differentially to the transgenic versus non-transgenic samples under study. Conclusion: Soybean endogenous allergen expression does not seem to be altered after genetic modification. Proteomics should be considered a powerful tool for functional characterization of plants and for food safety assessment.

Copyright $\odot 2007$ S. Karger AG, Basel

\section{Introduction}

Food allergy can be a serious nutritional problem in children and adults, and any protein-containing food has the potential to elicit an allergic reaction in the human population. Common symptoms of food allergy include skin irritations such as rashes, hives and eczema, and gastrointestinal symptoms such as nausea, diarrhoea and vomiting.

Antibody IgE-mediated reactions are the most prevalent allergic reactions to food. These responses occur af-

\section{KARGER}

Fax +41613061234 E-Mail karger@karger.ch www.karger.com
(ㄷ) 2007 S. Karger AG, Basel

$1018-2438 / 07 / 1441-0029 \$ 23.50 / 0$

Accessible online at:

www.karger.com/iaa
Correspondence to: Dr. Rita Batista

Instituto Nacional de Saúde Dr. Ricardo Jorge

Av. Padre Cruz

PT-1649-016 Lisboa (Portugal)

Tel. +351 21751 9316, Fax +351 21750 8153, E-Mail rita.batista@insa.min-saude.pt 
ter the release of chemical mediators from mast cells and basophiles as a result of interactions between food proteins and specific IgE molecules on the surface of these receptor cells $[1,2]$.

Eight foods or food groups have been identified as the most frequent sources of human food allergens and account for over $90 \%$ of the documented food allergies worldwide. These foods are milk, eggs, fish, crustaceans, wheat, peanuts, tree nuts and soya [3]. Despite their welldocumented allergenicity, soya derivatives continue to be increasingly used in a variety of food products due to their well-documented health benefits. Soybean (Glycine $\max$ ) has also been one of the selected target crops for genetic modification. Roundup Ready ${ }^{\circledR}$ (RUR) soya (Monsanto Co., St. Louis, Mo., USA), the most wellknown and widespread genetically modified (GM) soya, has the additional characteristic of being resistant to glyphosate. Glyphosate, the active substance of the Roundup herbicide, inhibits the enzyme EPSPS (5-enolpyruvylshikimate-3-phosphate synthase), which is essential for the biosynthesis of aromatic amino acids in plants and microorganisms. The introduction of CP4EPSPS protein (EPSPS from Agrobacterium tumefaciens $\mathrm{CP} 4$ strain) in this crop creates an alternative pathway which is insensitive to the Roundup ${ }^{\circledR}$ herbicide.

One of the major concerns regarding the safety of GM foods is the potential allergenicity of the resulting products, namely the possible occurrence of either altered or de novo expression of endogenous allergens after genetic manipulation. This concern justifies careful plant characterization. Two-dimensional gel electrophoresis is one of the most powerful proteomics tools for the separation and quantitation of proteins [4].

Combined with mass spectrometry (MS), two-dimensional gel electrophoresis allows rapid and reliable protein identification and can provide information about their post-translational modifications, subcellular localization, level of protein expression and protein-protein interactions [5].

Despite the importance of soybean and the availability of powerful tools for the analysis of its seed proteins, and specifically for the identification of allergens, only a limited number of reports has been published [6-10].

In this study we used two-dimensional gel electrophoresis followed by peptide tandem MS, to identify soya proteins. We used Western blotting to evaluate the IgE response of soya-allergic individuals, and tandem MS to categorize IgE-reactive proteins. Finally, we compared the IgE response of soya-allergic individuals under test both to GM RUR soya and its non-transgenic control.

\section{Material and Methods}

\section{Plant Materials}

The plant materials used for protein extraction, electrophoresis and immunoblotting, were purchased from the Institute of Reference Materials and Measurements (Geel, Belgium) and consisted of 5\% GM RUR soya flour and its $0 \%$ GM control.

\section{Protein Extraction}

One gram of each soya flour sample was ground in a mortar with liquid nitrogen and incubated with $10 \%(\mathrm{w} / \mathrm{v})$ trichloroacetic acid, $60 \mathrm{~mm}$ DTT in cold acetone at $-20^{\circ} \mathrm{C}$ for $1 \mathrm{~h}$. After centrifugation at $11,000 \mathrm{~g}$ for $15 \mathrm{~min}$ at $4^{\circ} \mathrm{C}$, pellets were incubated twice with $60 \mathrm{mM}$ DTT in acetone (cooled to $-20^{\circ} \mathrm{C}$ ) for $1 \mathrm{~h}$ and then centrifuged at $11,000 \mathrm{~g}$ for $15 \mathrm{~min}$ at $4^{\circ} \mathrm{C}$. The pellets were vacuum dried and stored at $-20^{\circ} \mathrm{C}$

For sodium dodecyl sulfate polyacrylamide gel electrophoresis (SDS-PAGE), the pellets were diluted 1:1 in sample buffer (0.125 M Tris-HCl, 4\% SDS, $20 \%$ v/v glycerol, 0.2 M DTT, $0.02 \%$ bromophenol blue, $\mathrm{pH}$ 6.8) and boiled for $5 \mathrm{~min}$ before electrophoresis.

For two-dimensional gel electrophoresis, the pellets obtained were dissolved in solubilization buffer [ $2 \mathrm{M}$ thiourea, $0.4 \%(\mathrm{v} / \mathrm{v})$ Triton X-100, 7 M urea, 4\% (w/v) CHAPS, 1\% immobilized $\mathrm{pH}$ gradient (IPG) buffer $3-11$.

The protein was measured according to Ramagli [11], with albumin from chicken egg white (Sigma, Sintra, Portugal) as standard.

Two-Dimensional Gel Electrophoresis of Total Proteins from Soya Flour

Isoelectric focusing was done on 13-cm-long IPG strips (Amersham Biosciences, Carnaxide, Portugal) with a non-linear $\mathrm{pH}$ gradient range of 3-11 in an IPGphor instrument (Amersham Biosciences). The strips were rehydrated for $12 \mathrm{~h}$ at $30 \mathrm{~V}$ in solubilization buffer diluted in $8 \mathrm{M}$ urea, $4 \%$ (w/v) CHAPS, 0.5\% (v/v) IPG buffer 3-11 and $60 \mathrm{mM}$ DTT to a final volume of $250 \mu \mathrm{l}$. After rehydration, focusing was done with the following program: $1 \mathrm{~h}$ at $250 \mathrm{~V}, 90 \mathrm{~min}$ at $500 \mathrm{~V}, 90 \mathrm{~min}$ at $1,000 \mathrm{~V}, 1 \mathrm{~h}$ at $2,500 \mathrm{~V}$, $24 \mathrm{~min}$ of a linear gradient to $8,000 \mathrm{~V}$ and $3 \mathrm{~h}$ at $8,000 \mathrm{~V}$. Prior to the second dimension, on SDS-PAGE, the IPG strips were equilibrated at room temperature for $15 \mathrm{~min}$ in $50 \mathrm{mM}$ Tris- $\mathrm{HCl}$, pH 8.8, $6 \mathrm{M}$ urea, 30\% (v/v) glycerol, 2\% (w/v) SDS and traces of bromophenol blue (equilibration buffer) plus $1 \%(\mathrm{w} / \mathrm{v}) \mathrm{DTT}$, followed by protein alkylation with $2.5 \%(\mathrm{w} / \mathrm{v})$ iodoacetamide in the equilibration buffer, at the same conditions of temperature and time. SDS-PAGE, on $12.5 \% \mathrm{~T}, 1.4 \% \mathrm{C}$ gels, was performed in a Hoefer SE 600 system (Amersham Biosciences). The gels were run with constant $40 \mathrm{~mA} /$ gel current, at $15^{\circ} \mathrm{C}$. Full Range Rainbow molecular weight markers (Amersham Biosciences) were used to calibrate the migration of the proteins.

The gels were stained with colloidal Coomassie blue [12].

For recovery of some spots we also used MS-compatible silver staining [13].

\section{IgE Immunoblot Reactivity Assay of Plasma from}

Soya-Allergic Patients

Patients' plasma was purchased from Plasmalab International (Everett, Wash., USA) and obtained from 5 individuals who had a positive history of documented soya allergy as well as positive 
specific UniCAP test values equal or higher than class 3 (Pharmacia Diagnostics; individuals 1-5, table 1) [14].

For negative controls, plasma from a non-allergic individual with a class 0 UniCAP test was used (individual 6, table 1).

IgE reactivity in the patient's plasma, against soya samples, was probed after two-dimensional gel electrophoresis followed by protein transfer onto Hybond ECL nitrocellulose membranes (Amersham Biosciences) of $400 \mu \mathrm{g}$ of total protein of $5 \%$ GM RUR soya and non-transgenic soya samples. Protein transfer was achieved, at $4^{\circ} \mathrm{C}$, by wet transfer in $25 \mathrm{~mm}$ Tris, $192 \mathrm{~mm}$ glycine, $0.1 \%$ SDS, $20 \%$ methanol, overnight at $20 \mathrm{~V}$.

Blots were blocked at $4{ }^{\circ} \mathrm{C}$, overnight, with PBS-T $(58 \mathrm{~mm}$ $\mathrm{Na}_{2} \mathrm{HPO}_{4}, 17 \mathrm{mM} \mathrm{NaH} \mathrm{PO}_{4} \cdot \mathrm{H}_{2} \mathrm{O}, 68 \mathrm{mM} \mathrm{NaCl}, 0.2 \%$ Tween 20 ) and $5 \%$ skimmed milk powder, and washed with $\mathrm{PBS}-\mathrm{T}$ prior to incubation for $90 \mathrm{~min}$ at room temperature, in plasma diluted 1:10 in blocking solution (first antibody incubation). After washing with PBS-T, the membranes were incubated at room temperature for $1 \mathrm{~h}$ with alkaline phosphatase-conjugated monoclonal anti-human-IgE (Southern Biotechnology Associates, Birmingham, Ala., USA) diluted 1:2,000 in blocking solution (second antibody incubation). After incubation, the membranes were washed with PBS-T and assay buffer and subsequently incubated for $5 \mathrm{~min}$ with CDP-Star solution with Nitro-Block II enhancer (Tropix Western-Star immunodetection system).

Blots were visualized after exposure to a high-performance chemiluminescence Hyperfilm ECL (Amersham Biosciences). For optimal signal intensity, the blots were exposed between $5 \mathrm{~s}$ and $30 \mathrm{~min}$

\section{Image Analysis}

For each individual tested we simultaneously ran 4 two-dimensional gels, 2 for $0 \%$ GM soya and 2 for 5\% RUR soya. From these 4 gels, 2 ( 1 from $0 \%$ GM and 1 from $5 \%$ GM soya) were transferred onto nitrocellulose membranes and the remaining 2 were stained with colloidal Coomassie blue. Stained gels and immunoblots were scanned with the ImageMaster Labscan (Amersham Biosciences) and images were analysed with the ImageMaster Platinum version 5.0 (Amersham Biosciences) and the Progenesis PG200 software. For image analysis, immunoblot films were compared with the average two-dimensional gel correspondent to each situation (average of the 6 stained gels for non-transgenic and GM soya).

\section{Tryptic Digestion of Two-Dimensional Electrophoresis Gel} Spots and MS Analysis

After excision from the gel, the protein spots were washed and destained, and digested with $0.25 \mu \mathrm{g}$ trypsin (Promega) in 100 $\mathrm{mM} \mathrm{NH}_{4} \mathrm{HCO}_{3}(\mathrm{pH} 8.0)$ at $37^{\circ} \mathrm{C}$ for $18 \mathrm{~h}$. The resulting peptides were analysed by capillary liquid chromatography tandem MS using a Magic C18 HPLC column $(100 \mu \mathrm{m} \times 10 \mathrm{~cm}$; Spectronex, Basel, Switzerland) connected on-line to a hybrid LTQ-Orbitrap or to a TSQ7000 instrument (Thermo Finnigan, San Jose, Calif., USA). A linear gradient from $5 \%$ solvent A ( $0.1 \%$ acetic acid) to $75 \%$ solvent $\mathrm{B}(0.1 \%$ acetic acid in $80 \%$ acetonitrile $)$ in $45 \mathrm{~min}$ was delivered with a Rheos 2200 HPLC system (Flux, Basel, Switzerland) at $100 \mu \mathrm{l} / \mathrm{min}$. A precolumn flow splitter reduced the flow to approximately $300 \mathrm{nl} / \mathrm{min}$ and the peptides were loaded onto the column with a $2-\mu$ lloop. The eluting peptides were ionized by electrospray ionization and the peptide ions were automatically selected and fragmented by collision-induced dissociation. When
Table 1. Patients included in the study

\begin{tabular}{lllcl}
\hline Patients & Age & Sex & $\begin{array}{l}\text { Soya-specific } \\
\text { UniCAP result, kUA/l }\end{array}$ & Class \\
\hline 1 & 35 & Male & $>100$ & 6 \\
2 & 40 & Female & 34.2 & 4 \\
3 & 37 & Male & 21.2 & 4 \\
4 & 47 & Female & 19.0 & 4 \\
5 & 29 & Female & 9.54 & 3 \\
6 & 34 & Male & $<0.35$ & 0 \\
\hline
\end{tabular}

using the Orbitrap, both precursor and fragment ion masses were measured in the Orbitrap analyser of the instrument.

\section{Database Search}

For data recorded on the Orbitrap instrument, individual MS/ MS spectra were databank searched using the TurboSEQUEST software [15], while data generated on the TSQ7000 instrument were searched with the Mascot [16] software. For all searches, the NCBI non-redundant databank was used.

\section{Quality of Transgenic Proteins in Soya Extracts}

To evaluate the presence or absence of CP4EPSPS protein in RUR soya and non-transgenic control, $30 \mathrm{mg}$ of each soya protein extract was separated by SDS-PAGE and immunoblotted with goat anti-CP4EPSPS serum (Monsanto Co.). One hundred micrograms of the same samples was applied onto two-dimensional gel electrophoresis and followed by immunoblotting.

\section{Electrophoresis and Protein Transfer to Nitrocellulose \\ Membranes}

After SDS-PAGE (0.75 mm thickness, $10 \%$ separating gel, $4 \%$ stacking gel) [17], the proteins were blotted at room temperature onto Hybond ECL nitrocellulose membranes (Amersham Biosciences) in $25 \mathrm{~mm}$ Tris, $192 \mathrm{~mm}$ glycine, $0.1 \%$ SDS, 20\% methanol for $1 \mathrm{~h}$ at $75 \mathrm{~V}$.

The two-dimensional gel electrophoresis was performed as described above (two-dimensional gel electrophoresis of total proteins from soya flour) except that the gels were stained with silver [18].

SDS-PAGE gel was stained with colloidal Coomassie blue [12].

\section{Immunodetection of CP4EPSPS}

The procedure was identical to the one described for IgE immunoblot reactivity assay of plasma from soya-allergic patients, with the following differences: (1) the first antibody incubation was performed with goat anti-CP4EPSPS serum (Monsanto Co.) diluted 1:5,000 in blocking solution; (2) the second incubation was performed with anti-goat IgG-AP conjugate (Sigma) diluted $1: 2,500$ in blocking solution. 
Table 2. Proteins identified in soya samples

\begin{tabular}{|c|c|c|c|c|c|c|}
\hline Spot No. & Protein identity & $\begin{array}{l}\text { NCBI Acces- } \\
\text { sion, number }\end{array}$ & $\begin{array}{l}\text { Source of the } \\
\text { matching protein }\end{array}$ & $\begin{array}{l}\text { Sequence } \\
\text { coverage, } \%\end{array}$ & $\begin{array}{l}\text { Matching } \\
\text { peptides }\end{array}$ & Mowse score \\
\hline 1 & $\beta$-conglycinin $\alpha$-chain precursor & gi:121281 & Glycine max & 20 & 17 & 571 \\
\hline 2 & prepro $\beta$-conglycinin $\alpha$-subunit & gi:75233296 & Glycine max & 21 & 18 & 710 \\
\hline 3 & $\alpha$-subunit of $\beta$-conglycinin (fragment) & gi: 75173468 & Glycine max & 18 & 14 & 509 \\
\hline 4 & $\beta$-conglycinin $\alpha$-subunit (fragment) & gi: 28629838 & Glycine max & 27 & 10 & 397 \\
\hline 5 & embryonic abundant protein, $59 \mathrm{~K}$ & gi:75102152 & Glycine max & 20 & 10 & 343 \\
\hline 6 & glycinin G1 precursor & gi:121276 & Glycine max & 16 & 7 & 325 \\
\hline 7 & $62 \mathrm{~K}$ sucrose-binding protein precursor & gi: 548900 & Glycine max & 14 & 7 & 257 \\
\hline $8 / 14$ & $\beta$-subunit of $\beta$-conglycinin & gi:75097336 & Glycine max & $39 / 28$ & $16 / 13$ & $704 / 495$ \\
\hline 9 & embryonic abundant protein, $59 \mathrm{~K}$ & gi:75102152 & Glycine max & 11 & 5 & 234 \\
\hline $10 / 11 / 12 / 13$ & $\beta$-conglycinin $\beta$-subunit & gi:15425635 & Glycine max & $19 / 28 / 20 / 20$ & $8 / 12 / 9 / 9$ & $376 / 604 / 437 / 420$ \\
\hline $15 / 17 / 19 / 20$ & $\beta$-conglycinin $\beta$-chain & gi:121282 & Glycine max & $17 / 14 / 14 / 16$ & $7 / 6 / 8 / 7$ & $264 / 263 / 320 / 264$ \\
\hline $21 / 22$ & alcohol dehydrogenase 1 (fragment) & gi:22597178 & Glycine $\max$ & $12 / 19$ & $6 / 8$ & $229 / 296$ \\
\hline $23 / 25$ & glyceraldehyde-3-phosphate dehydrogenase & gi:56069874 & Musa acuminata & $22 / 19$ & $8 / 6$ & $296 / 201$ \\
\hline $26 / 27 / 28$ & seed maturation protein $\mathrm{PM} 34$ & gi:9622153 & Glycine $\max$ & $18 / 18 / 32$ & $5 / 5 / 8$ & $205 / 197 / 317$ \\
\hline 29 & glycinin & gi:4249566 & Glycine max & 11 & 4 & 220 \\
\hline 30 & glycinin G2 precursor & gi:121277 & Glycine max & 8 & 3 & 187 \\
\hline $31 / 32 / 34 / 35 / 36$ & soybean agglutinin & gi:126151 & Glycine max & $12 / 34 / 32 / 48 / 11$ & $3 / 6 / 6 / 8 / 2$ & $104 / 201 / 230 / 304 / 79$ \\
\hline 38 & maturation-associated protein MAT9 & gi:282901 & Glycine max & 24 & 5 & 181 \\
\hline 39 & hypothetical protein At2g41050 & gi:75099863 & Arabidopsis thaliana & 4 & 1 & 50 \\
\hline 40 & basic 7S globulin precursor & gi:14549156 & Glycine $\max$ & 4 & 2 & 97 \\
\hline 41 & cysteine proteinase inhibitor & gi:75219003 & Glycine max & 20 & 4 & 137 \\
\hline $42 / 43$ & allergen Gly m Bd 28K (Fragment) & gi:12697782 & Glycine max & $6 / 9$ & $3 / 3$ & $93 / 116$ \\
\hline 44 & glycinin G1 precursor - soybean & gi:121276 & Glycine max & 5 & 3 & 95 \\
\hline 45 & seed maturation protein PM22 & gi:4585271 & Glycine max & 19 & 3 & 103 \\
\hline $46 / 47$ & allergen Gly m4, stress-induced SAM22 & gi:134194 & Glycine max & $29 / 9$ & $4 / 1$ & $202 / 31$ \\
\hline $48 / 49$ & glycine-rich RNA-binding protein & gi:5726567 & Glycine max & $9 / 9$ & $1 / 1$ & $64 / 54$ \\
\hline $50 / 51$ & soybean agglutinin fragment 2 & gi:126151 & Glycine max & $25 / 10$ & $3 / 1$ & $91 / 54$ \\
\hline 52 & proglycinin $\mathrm{A} 1 \mathrm{aB} 1 \mathrm{~b}$ homotrimer & gi:15988117 & Glycine max & 4 & 1 & 65 \\
\hline $53 / 54$ & glycinin G1 precursor & gi:121276 & Glycine max & $8 / 10$ & $4 / 5$ & $197 / 231$ \\
\hline 55 & glycinin G3 precursor & gi: 121278 & Glycine max & 15 & 9 & 440 \\
\hline 56 & glycinin G4 precursor & gi:99910 & Glycine max & 13 & 5 & 401 \\
\hline 57 & glycinin & gi:1772308 & Glycine max & 16 & 8 & 241 \\
\hline $58 / 59$ & proglycinin $\mathrm{A} 1 \mathrm{aB} 1 \mathrm{~b}$ homotrimer & gi: 15988117 & Glycine max & $10 / 3$ & $4 / 1$ & $150 / 59$ \\
\hline
\end{tabular}

Identification was not possible for spots 16, 18, 24, 33, 37, 60 and 61 .

\section{Results}

\section{Protein Identification and Functional Classification}

The complete list of soya proteins identified by MS is shown in table 2. Positive identification was based on a minimum of 2 unique peptides, with at least 1 of them having a significant score (individual ion score $>43$ ). From the 61 spots digested, protein matches were obtained for 55 . However, for 7 of the 55, no positive identification was found. These were spots 39, 48, 49, 51, 52 and 59 each with only 1 peptide having a significant score, and spot 47, also with only 1 matching peptide but without a significant matching score.

\section{Soya IgE-Binding Proteins}

The 5 soya-allergic individuals showed very different reactions against the soya proteome (fig. 1), illustrating the diversity of allergenic proteins present in this food crop and of individual responses. However, some common immunoreactive proteins were detected. All tested individuals showed immunoreaction against spots 42 and/or 43, which corresponds to an already characterized soya allergen, Gly m Bd 28k. Also, immunoreactivity of soybean agglutinin (lectin prepeptide) was found in all immunoblot films (spots 31, 32, 34-36, 50, 51). All the tested allergic individuals reacted at least to 1 of the 2 major types of soybean storage proteins, glycinin (spots 6, $29,30,44,52-59$ ) and conglycinin (spots 1-4, 8, 10-15, $17,19,20)$. Individuals 2,3 and 4 reacted against a pathogenesis-related protein already characterized as allergen (allergen Gly m 4 - spots 46 and 47). We also detected immunoreactivity against 2 proteins not previously identified as soya allergens: individuals 1, 2 and 3 reacted against an embryonic abundant polypeptide (spot 5 - ap- 
Table 3. Soya allergens already identified and its clinical relevance

\begin{tabular}{|c|c|c|c|}
\hline Allergens & Reference & Protein information & Sensitization \\
\hline $\begin{array}{l}\text { Soybean hydrophobic protein } \\
\text { (Gly m IA and Gly m IB) }\end{array}$ & $\begin{array}{l}\text { Gonzalez et al., } 1992 \text { [33]; } \\
\text { Gonzalez et al., } 1995 \text { [34] }\end{array}$ & $\begin{array}{l}\text { NCBI entry: gi:123506 } \\
\text { Mr/pI: } 8.4 \mathrm{kDa} / 6.2 \text { (theoretical); } 7.5 \text { and } \\
7.0 \mathrm{kDa} / 6.8 \text { and } 6.1-6.2 \text { (experimental) [33] }\end{array}$ & $\begin{array}{l}20 \text { subjects with asthma and sensitized to } \\
\text { soy: } 95 \% \text { IgE positive [33] }\end{array}$ \\
\hline $\begin{array}{l}\text { Soybean hull protein } \\
(\text { Gly } \mathrm{m} 2)\end{array}$ & Codina et al., 1997 [35] & $\begin{array}{l}\text { NCBI entry: gi:1362049 } \\
\text { Mr/pI: } 8.0 \mathrm{kDa} / 6.0 \text { (experimental) [35] }\end{array}$ & $\begin{array}{l}32 \text { subjects who suffered attacks during the } \\
\text { asthma outbreaks of } 1987 \text { and } 1988: 90 \% \\
\text { IgE positive to shell components [36] }\end{array}$ \\
\hline Profilin (Gly m 3) & Rihs et al., 1999 [37] & $\begin{array}{l}\text { NCBI entry: gi:3914436, gi:3914435 } \\
\text { Mr/pI: } 14.1 \mathrm{kDa} / 4.4-4.6 \text { (theoretical) }\end{array}$ & $\begin{array}{l}13 \text { soybean-sensitized subjects: } 69 \% \text { IgE } \\
\text { positive [37]; } 22 \text { subjects allergic to birch } \\
\text { pollen with soy allergy: } 25 \% \text { IgE positive } \\
\text { [38] }\end{array}$ \\
\hline $\begin{array}{l}\text { Stress-induced protein SAM22 } \\
\text { (Gly m 4) }\end{array}$ & Crowell et al., 1992 [39] & $\begin{array}{l}\text { NCBI entry: gi:134194 } \\
\text { Mr/pI: } 16.7 \mathrm{kDa} / 4.7 \text { (theoretical) }\end{array}$ & $\begin{array}{l}20 \text { birch pollen-sensitized subjects: } 85 \% \text { IgE } \\
\text { positive [40]; } 22 \text { subjects allergic to birch } \\
\text { pollen with soy allergy: } 95.4 \% \text { IgE positive } \\
\text { [38] }\end{array}$ \\
\hline $\begin{array}{l}\alpha \text { subunit of } \beta \text {-conglycinin } \\
(\text { Gly } \mathrm{m} \mathrm{Bd} 60 \mathrm{~K})\end{array}$ & Ogawa et al., 1991 [41] & $\begin{array}{l}\text { NCBI entry: gi: } 121281 \\
\text { Mr/pI:51.1-74.5 kDa/5.1-5.9 (theoretical); } \\
53.7-104.8 \mathrm{kDa} / 4.5-6.3 \text { (experimental) [8] }\end{array}$ & $\begin{array}{l}\text { Soybean-sensitized subjects with atopic } \\
\text { dermatitis: } 15 \% \text { IgE positive [ } 41]\end{array}$ \\
\hline $\begin{array}{l}\text { Soybean vacuolar protein } \\
\text { (Gly m Bd } 30 \mathrm{~K}, \mathrm{P} 34,34 \mathrm{kDa} \\
\text { maturing seed protein) }\end{array}$ & $\begin{array}{l}\text { Ogawa et al., } 1991 \text { [41]; } \\
\text { Ogawa et al., } 1993 \text { [42] }\end{array}$ & $\begin{array}{l}\text { NCBI entry: gi:75278295 } \\
\text { Mr/pI: } 42.8 \mathrm{kDa} / 5.6 \text { (theoretical); } \\
\sim 30 \mathrm{kDa} / 4.5-5 \text { (experimental) [7] }\end{array}$ & $\begin{array}{l}\text { Soybean-sensitized subjects with atopic } \\
\text { dermatitis: } 65 \% \text { IgE positive }[41,42]\end{array}$ \\
\hline $\begin{array}{l}\text { Vicilin-like glycoprotein } \\
(\text { Gly m Bd } 28 \mathrm{~K})\end{array}$ & $\begin{array}{l}\text { Ogawa et al., } 1991[41] \\
\text { Tsuji et al., } 2001[43]\end{array}$ & $\begin{array}{l}\text { NCBI entry: gi: } 12697782 \\
\text { Mr/pI: } 52.6 \mathrm{kDa} / 5.7 \text { (theoretical); } \\
22 \mathrm{kDa} / 7.1 \text { (experimental) [8] }\end{array}$ & - \\
\hline Glycinin & Djurtoft et al., 1991 [44] & $\begin{array}{l}\text { NCBI entry: gi: } 4249566 \\
\text { Mr/pI: } 58.2-58.4 \mathrm{kDa} / 5.5 \text { (theoretical); } \\
\text { 42.9-55.9 kDa/6.0-8.4 (experimental) [8] }\end{array}$ & $\begin{array}{l}10 \text { soybean-sensitized subjects: glycinin in } \\
90 \% \text {, glycinin subunits in } 100 \% \text { [44] }\end{array}$ \\
\hline $\begin{array}{l}\text { Methionine-rich protein } \\
\text { (Gly m 2S albumin, GM2S-1) }\end{array}$ & Gu et al., 2001 [45] & $\begin{array}{l}\text { NCBI entry: gi: } 5902685 \\
\text { Mr/pI: } 18.4 \mathrm{kDa} / 5.2 \text { (theoretical); } \\
12 \mathrm{kDa} \text { (experimental) [45] }\end{array}$ & $\begin{array}{l}16 \text { soybean-sensitized subjects: } 0 \% \operatorname{IgE} \\
\text { positive [46] }\end{array}$ \\
\hline Gly m $39 \mathrm{~K}$ & Gu et al., 2001 [45] & 39Kda (experimental) [46] & - \\
\hline $\begin{array}{l}\text { Agglutinin, lectin precursor } \\
\text { (Gly m lectin) }\end{array}$ & Barnett et al., 1987 [47] & $\begin{array}{l}\text { NCBI entry: gi: } 126151 \\
\text { Mr/pI: } 30.9 \mathrm{kDa} / 5.7 \text { (theoretical) }\end{array}$ & $\begin{array}{l}16 \text { soybean-sensitized subjects: } 31.2 \% \operatorname{IgE} \\
\text { positive [ } 46] ; 14 \text { soybean-sensitized } \\
\text { asthmatic bakers: } 21 \% \text { IgE positive [ } 48]\end{array}$ \\
\hline $\begin{array}{l}\text { Kunitz trypsin inhibitor } \\
\text { (Gly m TI) }\end{array}$ & $\begin{array}{l}\text { Moroz et al., } 1980[49] \\
\text { Burks et al., } 1994[50] \\
\text { Baur et al., } 1996[48]\end{array}$ & $\begin{array}{l}\text { NCBI entry: gi:3318877 } \\
\text { Mr/pI: } 20.1 \mathrm{kDa} / 4.6 \text { (theoretical); } \\
20.3 \mathrm{kDa} / 4.6 \text { (experimental) [10] }\end{array}$ & $\begin{array}{l}5 \text { subjects with atopic dermatitis and } \\
\text { soy allergy: } 20 \% \text { IgE positive [50]; } 16 \\
\text { soybean-sensitized subjects: } 6 \% \text { IgE positive } \\
\text { [46]; } 14 \text { soybean-sensitized asthmatic } \\
\text { bakers: } 86 \% \text { IgE positive [48] }\end{array}$ \\
\hline
\end{tabular}

parent $\mathrm{pI} / \mathrm{Mr} \sim 6.1 / 60 \mathrm{kDa}$, and spot 9 - apparent $\mathrm{pI} / \mathrm{Mr}$ $\sim 6.1 / 50 \mathrm{kDa}$ ) and individual 2 against a cysteine proteinase inhibitor (spot 41 - apparent $\mathrm{pI} / \mathrm{Mr} \sim 6.3 / 25 \mathrm{kDa}$ ). Finally, we think it is important to point out the presence of spot 61 (apparent $\mathrm{pI} / \mathrm{Mr} \sim 4.9 / 25 \mathrm{kDa}$ ) in the immunoblot of individual 1 (fig. 1b), although its identity could not be revealed by MS. This spot may also correspond to a new allergen.

The plasma from the non-allergic individual, used as a negative control, showed no immunoreaction against the soya proteome (data not shown).

\section{GM versus Non-GM Samples}

As expected, CP4EPSPS was detected in 5\% GM soya and was absent in the non-transgenic sample. The migration of the protein was in accordance with the calculated molecular weight of $46 \mathrm{kDa}$ (online suppl. fig. 1, www. karger.com/doi/10.1159/000102611. Regarding the differences between GM and non-GM samples, the only differential spot obtained in this study was spot 5 , which appeared only in the 5\% GM soya immunoblot of individual 3 . However, the same spot was also found in the non-GM soya sample (fig. 1,2 ).

Int Arch Allergy Immunol 2007;144:29-38 


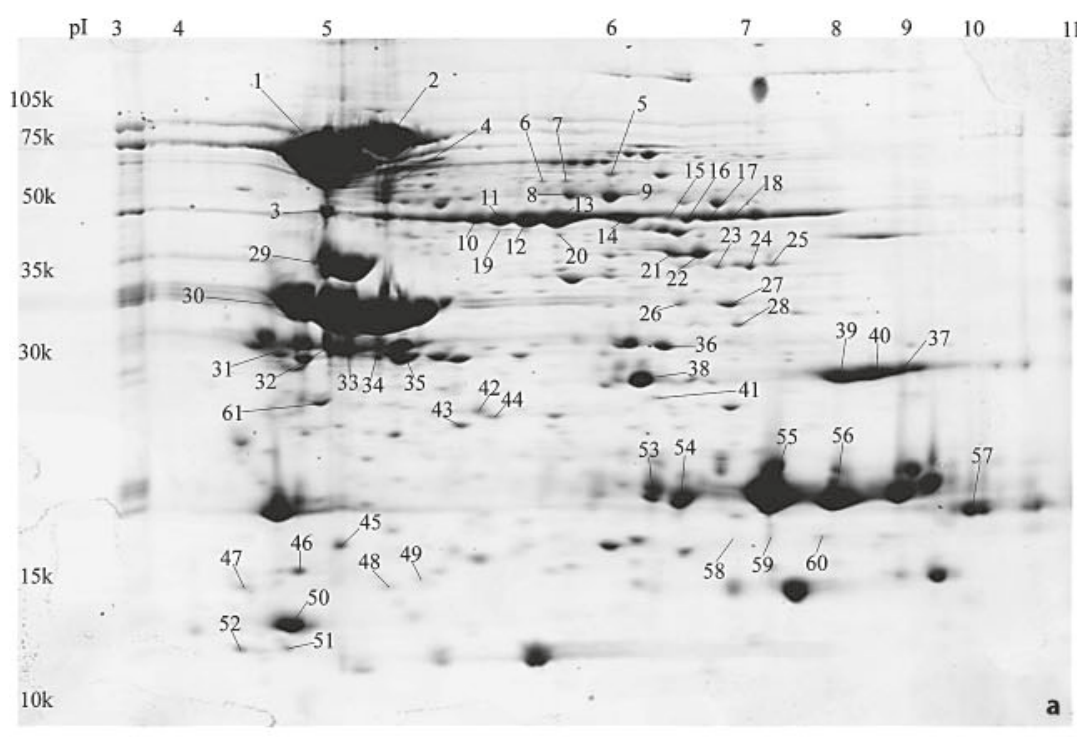

Fig. 1. Two-dimensional electrophoretic protein pattern of non-GM soya extract (a) and IgE antibody reactivity assay from soya-allergic patients (b-f). b-f IgE immunoblots of individuals 1-5 against non-GM soya sample. Two-dimensional gels were run with $400 \mu \mathrm{g}$ of total protein, in $12.5 \%$ gels and were stained with colloidal Coomassie blue. $\mathrm{k}=\mathrm{kDa}$.
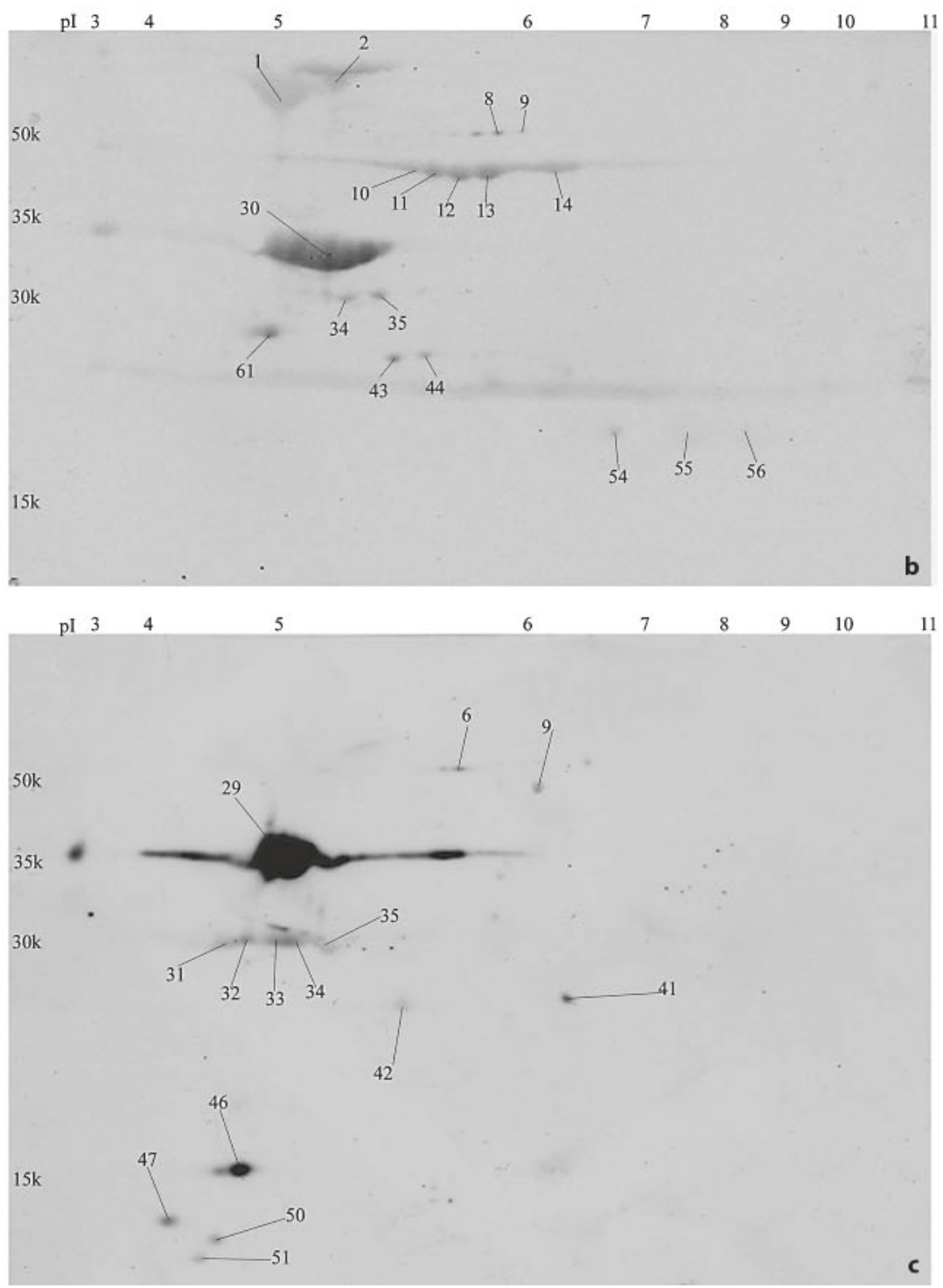

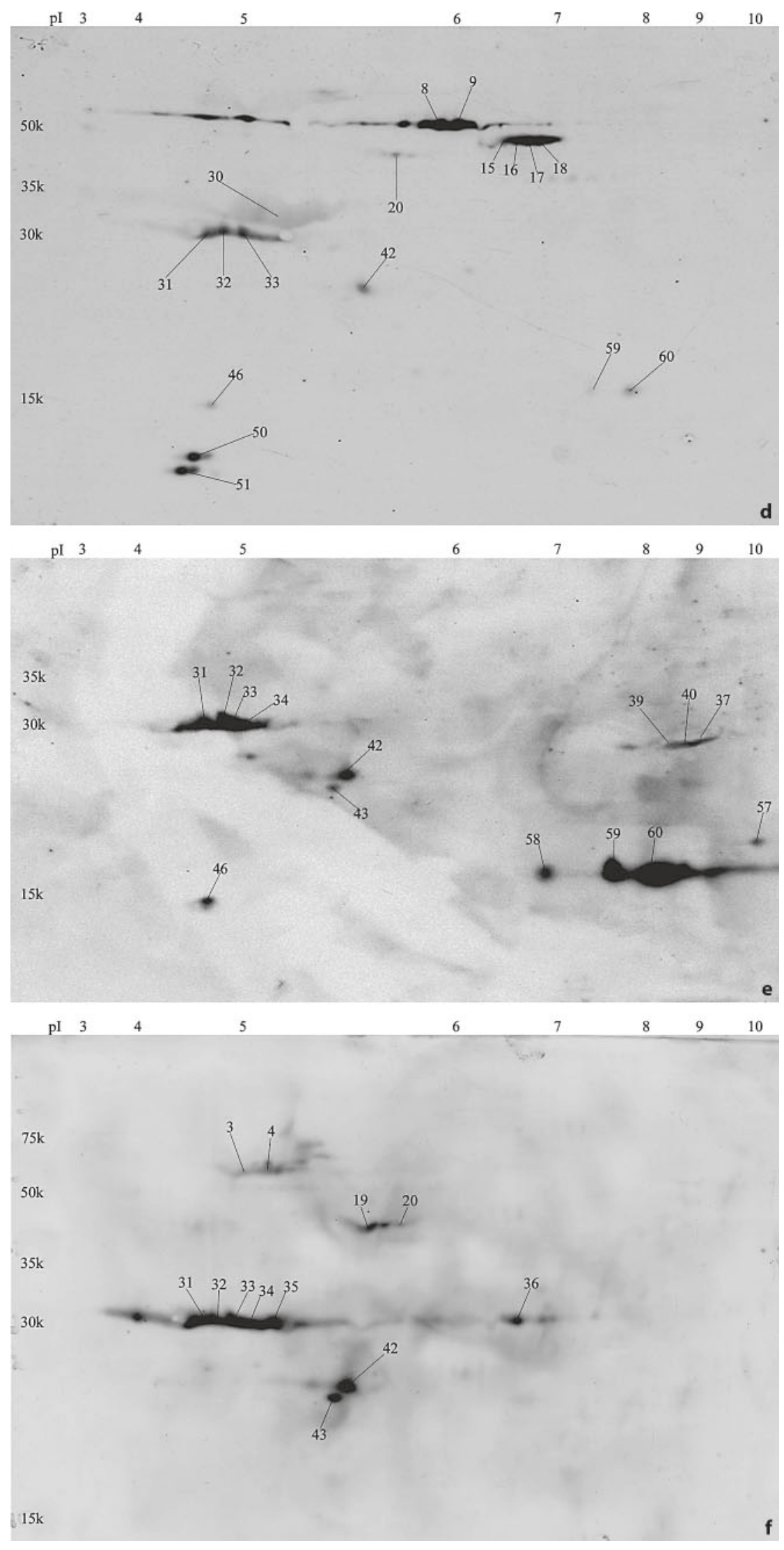

Fig. 1. d-f 
Fig. 2. Protein electrophoretic patterns (a) and IgE antibody reactivity assay (b) from soya-allergic patient $3 . \mathrm{k}=\mathrm{kDa}$; RUR+ = $5 \%$ RUR soya.

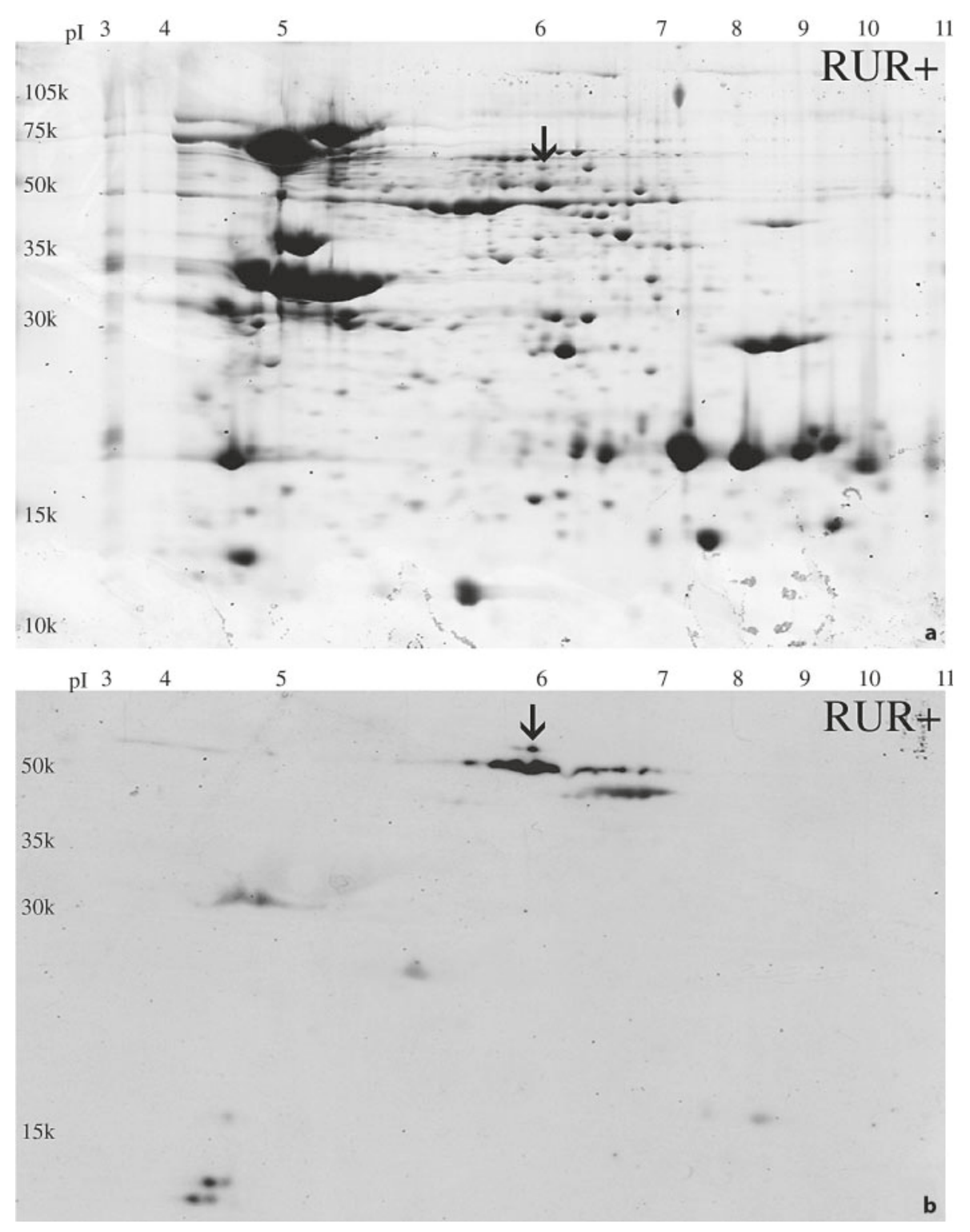

\section{Discussion}

Soybean is known to be one of the major allergenic foods. There are already some allergens identified from soybean (table 3 ) and a few databases where this information can be retrieved. In the present study, we could confirm some of the already described soybean allergens. However, besides the major inhalant allergens Gly m IA, Gly m IB, Gly m 2 and Kunitz trypsin inhibitor, it was not possible to identify a positive reaction against 2 highly allergenic soya proteins - the immunodominant soybean allergen Gly $\mathrm{m} \mathrm{Bd} 30 \mathrm{k}$ and profilin - in any of the soybean-sensitive individuals [19, 20,37]. Gly $\mathrm{m} \mathrm{Bd} 30 \mathrm{k}$ is a relatively minor seed constituent that appears in the two-dimensional electrophoresis map zone of soybean agglutinin (spots 31-36) [7]. In our study, all the individuals tested seemed to react against agglutinin which was abundantly present in the two-dimensional electrophoresis gels. Therefore, it is likely that Gly m Bd $30 \mathrm{k} \mathrm{IgE}$ reaction was masked by soybean agglutinin abundance. Non-identification of profilin is justified by the fact that the disruption of its tertiary structure causes a loss of the IgE-binding activity [37]. We identified 2 new potential soybean allergens - a maturation-associated protein (spots 5 and 9) and a cysteine proteinase inhibitor (spot 41). The embryonic abundant protein 
(spots 5 and 9) contains several repeats of the late embryogenesis abundant domains, indicating that this protein is a late embryogenesis abundant protein. Different types of late embryogenesis abundant proteins are expressed at different stages of late embryogenesis in higher plant seed embryos and under conditions of dehydration stress [21]. Spot 41 corresponds to a soya cystatin. Cystatins are proteins that inhibit cysteine proteases by direct interaction with the active site. These proteins are normally involved in defence reactions against biotic and abiotic stresses [22-24].

The possible association between stress response and allergenicity has already been documented with pathogenesis-related proteins emerging as an increasingly important group of plant-derived allergens $[25,26]$.

To evaluate putative modifications induced by genetic manipulation in GM food crops, proteomic analyses may be an important tool. This approach was already suggested by others and used in 'substantial equivalence' studies $[27,28]$. Substantial equivalence is an internationally recognized standard that measures whether a biotech food or crop shares similar health and nutritional characteristics with its conventional counterpart. In its basic form, substantial equivalence is an analytical evaluation that compares the composition of the food/feed component under review with an existing food/feed or food/feed component that humans or animals already safely consume. The assessment relies on validated methods.

In this study, we extended this approach to soybean to evaluate the possibility of altered expression of endogenous allergens after genetic manipulation for herbicide resistance (RUR soya). With this goal we have established two-dimensional electrophoresis maps of a 5\% GM RUR sample and its non-transgenic homologue (control) and we have compared the IgE response of sensitive individuals to both plant types.

As already mentioned in the results section, the only difference encountered between soybean-allergic individ- uals' response to transgenic versus non-transgenic soya samples corresponded to spot number 5 , which was only present in the transgenic immunoblot of individual 3, but also present in the two-dimensional electrophoresis gel of the non-transgenic soya sample (fig. 1, 2). Spots 5 and 9 corresponded to the same protein (table 2), and spot 9 was present in both immunoblots. According to the migration of spots 5 and 9 in two-dimensional gel electrophoresis, it seems that spot 5 derived from spot 9 and that the observed difference is possibly related to the variation in migration during electrophoresis. These results seem to be in accordance with the ones obtained by us in a previous study for the evaluation of potential allergenicity of GM food crops, where RUR soya was included [29].

There are no methods universally applicable to the assessment of potential allergenicity of GM organisms. However, there are recommendations for the analysis of the gene(s) introduced into an organism and of the derived protein(s) expressed in such organisms [30-32].

The growing use of diverse and multiple genes that may affect metabolic pathways and the coding or regulatory genetic elements, by transgenic insertion or genomic rearrangements, makes the analysis of gene(s) and their expressed protein(s) insufficient. Therefore, new methods that allow a global gene or protein screening are increasingly desired and useful for detection of potential pleiotropic effects of genetic modification.

We believe, and tried to demonstrate in this study, that proteomics should be considered a powerful tool in the functional characterization of plants as well as in the assessment of food safety.

\section{Acknowledgements}

This work was supported by the Fundação Calouste Gulbenkian (research project SDH.SP.I.01.11). We gratefully acknowledge Dr. Margarida Krause for the final revision of the manuscript.

\section{References}

Human IgE Response to Soya
1 Taylor SL, Lehrer SB: Principles and characteristics of food allergens. Crit Rev Food Sci Nutr 1996;36(suppl):S91-S118.

$\checkmark 2$ Helm RM, Burks AW: Mechanisms of food allergy. Curr Opin Immunol 2000;12:647-653.

3 Food and Agriculture Organization of the United Nations: Report of the FAO Technical Consultation on Food Allergies. Rome, Food and Agriculture Organization of the United Nations, 1995.

4 Herbert B: Advances in protein solubilization for two-dimensional electrophoresis. Electrophoresis 1999;20:660-663.
5 Pandey A, Mann M: Proteomics to study genes and genomes. Nature 2000;405:837846.

6 Magni C, Ballabio C, Restani P, Sironi E, Scarafoni A, Poiesi C, Duranti M: Two-dimensional electrophoresis and Western-blotting analyses with anti Ara h 3 basic subunit IgG evidence the cross-reacting polypeptides of Arachis hypogaea, Glycine max, and Lupinus albus seed proteomes. J Agric Food Chem 2005;53:2275-2281. 
$>7$ Herman EM, Helm RM, Jung R, Kinney AJ: Genetic modification removes an immunodominant allergen from soybean. Plant Physiol 2003;132:36-43.

$>8$ Hajduch M, Ganapathy A, Stein JW, Thelen JJ: A systematic proteomic study of seed filling in soybean. Establishment of high-resolution two-dimensional reference maps, expression profiles, and an interactive proteome database. Plant Physiol 2005;137:1397-1419.

$\checkmark 9$ Mooney BP, Thelen JJ: High-throughput peptide mass fingerprinting of soybean seed proteins: automated workflow and utility of UniGene expressed sequence tag databases for protein identification. Phytochemistry 2004;65:1733-1744.

-10 Natarajan S, Xu C, Caperna TJ, Garret WM: Comparison of protein solubilization methods suitable for proteomic analysis of soybean seed proteins. Anal Biochem 2005;342:214220.

11 Ramagli LS: Quantifying protein in 2DPAGE solubilization buffers. Methods Mol Biol 1999;112:99-103.

$\checkmark 12$ Neuhoff V, Stamm R, Eibl H: Clear background and highly sensitive protein staining with Coomassie Blue dyes in polyacrylamide gels: a systematic analysis. Electrophoresis 1985;6:427-448.

13 Pandey A, Anderson JS, Mann M: Use of mass spectrometry to study signaling pathways. Sci STKE 2000;37:PL1.

14 Axén R, Drevin H, Kober A, Yman L: A new laboratory diagnostic system applied to allergy testing. N Engl Reg Allergy Proc 1988;9: 503.

-15 Gatlin CL, Eng JK, Cross ST, Detter JC, Yater JR 3rd: Automated identification of amino acid sequence variations in proteins by HPLC/ microspray tandem mass spectrometry. Anal Chem 2000;72:757-763.

16 Perkins DN, Pappinl DJC, Creasy DM, Cottrell JS: Probability-based protein identification by searching databases using mass spectrometry data. Electrophoresis 1999;20: 3551-3567.

$\checkmark 17$ Laemmli UK: Cleavage of structural proteins during the assembly of the head of bacteriophage T4. Nature 1970;227:680-685.

18 Blum H, Beier H, Gross HJ: Improved silver staining of plant-proteins, RNA and DNA in polyacrylamide gels. Electrophoresis 1987;8: 93-99.

19 Yaklich R, Helm R, Herman E: Analysis of the distribution of the major soybean allergen in a core collection of Glycine max accessions. Crop Sci 1999;39:1444-1447.

20 Helm RM, Cockrell G, Herman E, Burks AW, Sampson HA, et al: Cellular and molecular characterization of a major soybean allergen. Int Arch Allergy Immunol 1998;117:29-37.
1 Ali-Benali MA, Alary R, Joudrier P, Gautier M-F: Comparative expression of five Lea genes during wheat seed development and in response to abiotic stresses by real-time quantitative RT-PCR. Biochim Biophys Acta 2005; 1730:56-65.

22 Koiwa H, Shade RE, Zhu-Salzman K, D’Urzo MP, Murdock LL, et al: A plant defensive cystatin (soyacystatin) targets cathepsin L-like digestive cysteine proteinases (DvCALs) in the larval midgut of western corn rootworm (Diabrotica virgifera virgifera). FEBS Lett 2000;471:67-70.

23 Arai S, Matsumoto I, Emori Y, Abe K: Plant seed cystatins and their target enzymes of endogenous origin. J Agric Food Chem 2002;50: 6612-6617.

24 Massonneau A, Condamine P, Wisniewski J-P, Zivy M, Rogowsky PM: Maize cystatins respond to developmental cues, cold stress and drought. Biochim Biophys Acta 2005; 1729:186-199.

25 Midoro-Horiuti T, Brooks EG, Goldblum RM: Pathogenesis-related proteins of plants as allergens. Ann Allergy Asthma Immunol 2001;87:261-271.

26 Hoffmann-Sommergruber K: Pathogenesisrelated (PR)-proteins identified as allergens. Biochem Soc Trans 2002;30:930-935.

27 Corpillo D, Gardini G, Vaira AM, Basso M, Aime S, et al: Proteomics as a tool to improve investigation of substantial equivalence in genetically modified organisms: the case of a virus-resistant tomato. Proteomics 2004;4:193200.

28 Lehesranta SJ, Davies HV, Shepherd LVT, Nunan N, McNicol JW, et al: Comparison of tuber proteomes of potato varieties, landraces, and genetically modified lines. Plant Physiol 2005;138:1690-1699.

29 Batista R, Nunes B, Carmo M, Cardoso C, José HS, et al: Lack of detectable allergenicity of transgenic maize and soya samples. J Allergy Clin Immunol 2005;116:403-410.

30 Metcalfe DD: Genetically modified crops and allergenicity. Nat Immunol 2005;6:857-860.

31 Taylor SL: Assessment of the allergenicity of genetically modified foods. Nutr Abstracts Rev (Series A) 1997;67:1163-1168.

32 Mendieta NLR, Nagy A-M, Lints FA: The potential allergenicity of novel foods. J Sci Food Agric 1997;75:405-411.

33 Gonzalez R, Polo F, Zapatero L, Caravaca F, Carreira J: Purification and characterization of major inhalant allergens from soybean hulls. Clin Exp Allergy 1992;22:748-755.

34 Gonzalez R, Varela J, Carreira J, Polo F: Soybean hydrophobic protein and soybean hull allergy. Lancet 1995;346:48-49.

35 Codina R, Lockey RF, Fernandez-Caldas E, Rama R: Purification and characterization of a soybean hull allergen responsible for the Barcelona asthma outbreaks. 2. Purification and sequencing of the Gly $\mathrm{m} 2$ allergen. Clin Exp Allergy 1997;27:424-430.

>36 Gonzalez R, Zapatero L, Caravaca F, Carreira J: Identification of soybean proteins responsible for respiratory allergies. Int Arch Allergy Appl Immunol 1991;95:53-57.
37 Rihs HP, Chen Z, Rueff F, Petersen A, Rozynek $P$, et al: IgE binding of the recombinant allergen soybean profilin (rGly m 3 ) is mediated by conformational epitopes. J Allergy Clin Immunol 1999;104:1293-1301.

38 Mittag D, Vieths S, Vogel L, Becker WM, Rihs $\mathrm{HP}$, et al: Soybean allergy in patients allergic to birch pollen: clinical investigation and molecular characterization of allergens. J Allergy Clin Immunol 2004;113:148-154.

39 Crowell DN, John ME, Russell D, Amasino RM: Characterization of a stress-induced, developmentally regulated gene family from soybean. Plant Mol Biol 1992;18:459-466.

40 Kleine-Tebbe J, Vogel L, Crowell DN, Haustein UF, Vieths S: Severe oral allergy syndrome and anaphylactic reactions caused by a Bet $\mathrm{v}$ 1-related PR-10 protein in soybean, SAM22. J Allergy Clin Immunol 2002;110: 797-804.

41 Ogawa T, Bando N, Tsuji H, Okajima H, Nishikawa $\mathrm{K}$, et al: Investigation of the IgEbinding proteins in soybeans by immunoblotting with the sera of the soybean-sensitive patients with atopic dermatitis. J Nutr Sci Vitaminol (Tokyo) 1991;37:555-565.

42 Ogawa T, Bando N, Tsuji H, Nishikawa K, Kitamura K: Identification of the soybean allergenic protein, Gly $\mathrm{m}$ Bd $30 \mathrm{~K}$, with the soybean seed $34-\mathrm{kDa}$ oil-body-associated protein. Biosci Biotechnol Biochem 1993;57: 1030-1033.

43 Tsuji H, Hiemori M, Kimoto M, Yamashita H, Kobatake R, et al: Cloning of cDNA encoding a soybean allergen, Gly $\mathrm{m} \mathrm{Bd} 28 \mathrm{~K}$. Biochim Biophys Acta 2001;1518:178-182.

44 Djurtoft R, Pedersen HS, Aabin B, Barkholt V: Studies of food allergens: soybean and egg proteins. Adv Exp Med Biol 1991;289:281293.

45 Gu X, Beardslee T, Zeece M, Sarath G, Markwell J: Identification of IgE-binding proteins in soy lecithin. Int Arch Allergy Immunol 2001;126:218-225.

46 Lin J, Shewry PR, Archer DB, Beyer K, Niggemann $B$, et al: The potential allergenicity of two $2 \mathrm{~S}$ albumins from soybean (Glycine max): a protein microarray approach. Int Arch Allergy Immunol 2006;141:91-102.

47 Barnett D, Howden ME: Lectins and the radioallergosorbent test. J Allergy Clin Immunol 1987;80:558-561.

48 Baur X, Pau M, Czuppon A, Fruhmann G: Characterization of soybean allergens causing sensitization of occupationally exposed bakers. Allergy 1996;51:326-330.

49 Moroz LA, Yang WH: Kunitz soybean trypsin inhibitor: a specific allergen in food anaphylaxis. N Engl J Med 1980;302:1126-1128.

50 Burks AW, Cockrell G, Connaughton C, Guin J, Allen W, et al: Identification of peanut agglutinin and soybean trypsin inhibitor as minor legume allergens. Int Arch Allergy Immunol 1994;105:143-149. 